\title{
Optimal Thickness and Heating Time Based on Physical and Mechanical Properties of Densified Sengon Board
}

\author{
Iskandar ${ }^{1, *}$ Edy Budiarso ${ }^{2}$ Isna Yuniar Wardhani ${ }^{2}$ Agus Sulistyobudi ${ }^{2}$ \\ ${ }^{1}$ Teknologi Hasil Hutan, POLTANESA, Kampus Gn. Panjang, Samarinda, 75131 \\ ${ }^{2}$ Teknologi Hasil Hutan, UNMUL, Kampus Gn. Kelua, Samarinda, 75119 \\ ${ }^{*}$ Corresponding author. Email: iskandar.smd.799@gmail.com
}

\begin{abstract}
Sengon is classified as low density wood. It is widely planted in the plantation forest so that it has a high potency for industry. Therefore, it is necessary to increase the strength of its wood through densification as one way. The results showed that fluctuation in water-content reduction were only about $1 \%$ of the control. Based on the result of the Dunnet test, which tested the average of control compared with the average of treatment results, it showed a significant increase in wood density in all initial thicknesses. Dunnet test on the firmness of parallel press fibers showed that the compaction treatment was significantly affected the initial thickness of $3.0 \mathrm{~cm}$ and $3.5 \mathrm{~cm}$, while at the initial thickness of $2.5 \mathrm{~cm}$ it did not give a significant effect. In the hardness test of parallel wood, the given solid compaction has a significant effect on the initial thickness of $3.0 \mathrm{~cm}$ and $3.5 \mathrm{~cm}$, while at the initial thickness of 2.5 $\mathrm{cm}$ does not give a real effect. While for the hardness test of wood perpendicular to the compressed press that was given only had a significant effect on the initial thickness of $3.5 \mathrm{~cm}$ and did not give a significant effect on the initial thickness of 2.5 and $3.0 \mathrm{~cm}$. Based on the result of this study, it can be concluded that the optimal treatment of several combinations of initial thickness, the bestresult of treatment is on wood of an initial thickness of $3.5 \mathrm{~cm}$ and the best heating time is of duration of 6 minutes, because it was found that in these conditions there is a significant increase to some value of criteria that were tested.
\end{abstract}

Keywords: Densification, Density, Hardness

\section{INTRODUCTION}

Wood as forest main product can be utilized in various needs for supporting life. The rapid growth of population and advanced technology causes the increasing need against wood raw material; however, wood availability is declining.

The fast growing type of wood and the medium growing one is still majorly found and available which makes them possible to be utilized as the replacement for high qualified wood that is scarcely found; this research used sengon. Sengon tree has quite high potential and is spread all over Indonesia which is included into fast growing tree. Sengon is less interested in craftsmanship world due to its low strong level (level IV strength).
The weakness of sengon when used as construction law material is because of its low specific gravity. A variety of wood management technology has been developed and available in accordance with todays' advanced science and technology that various products of different technology of wood processing technology both from their original materials and in the form of dimension, nature and quality are well-known. The technology currently being developed that aims to increase wood density is by means of wood densification.

USDA (1999) in [1] describes that densification enhances the properties of wood strengths such as flekstural (MOE, MOR and tension at the proportional limit), compressive strength, tensile strength, shear strength, stiffness and strength of the average beat greater than $150 \%$. The wood densification process is influenced by several factors such as wood type, early 
wood density, pre-treatment before the pressing process, wood plasticity, moisture content, temperature, and felting time. The purpose of this research was to know the influence of the initial thickness and pressing time as well as the interaction of these two factors toward the physical and mechanical properties of sengon wood which is densified and know the correct pressing time to obtain better physical and mechanical properties of sengon wood. The benefit of this research was to provide information on the densification process of the sengon wood species so that the quality can be improved so that the nature of its use is broader biased.

\section{MATERIALS AND METHODS}

Wood hardness test parallel and perpendicular to the pressing parallel and compressive strength parallel to the fiber were tested by Universal Testing Machine (UTM), while to determine the moisture content and density used oven and weighing method and the result is calculated by the formula of Moisture content and Density.The material used was sengon wood (Paraserianthes falcataria).

\subsection{Wood Sample Preparation Procedure}

The sengon tree (Paraserianthes falcataria) used was about $80 \mathrm{~cm}$ in diameter. Samples were taken on the straight part in the middle of the stem, then a board measuring $4 \mathrm{~cm}$ thick and 2 meters long was made. For the needs of this sample the wood used was between the radial and tangential plane (about $10 \mathrm{~cm}$ from the pith and $10 \mathrm{~cm}$ from the edge of the stem). This board was left for about 3 months and placed in the open air. Furthermore, from the board, a sample material was made measuring: $40 \mathrm{~m} \times 40 \mathrm{~cm} \times 2.0 \mathrm{~cm}$ for 1 chip (control), $40 \mathrm{~cm} \times 40 \mathrm{~cm} \mathrm{x} 2.5 \mathrm{~cm}$ for 1 chip, $40 \mathrm{~cm} \mathrm{x}$ $40 \mathrm{~cm} \times 3.0 \mathrm{~cm}$ for $1 \mathrm{chip}$, and $40 \mathrm{~cm} \times 40 \mathrm{~cm} \times 3.5 \mathrm{~cm}$ for 1 chip.

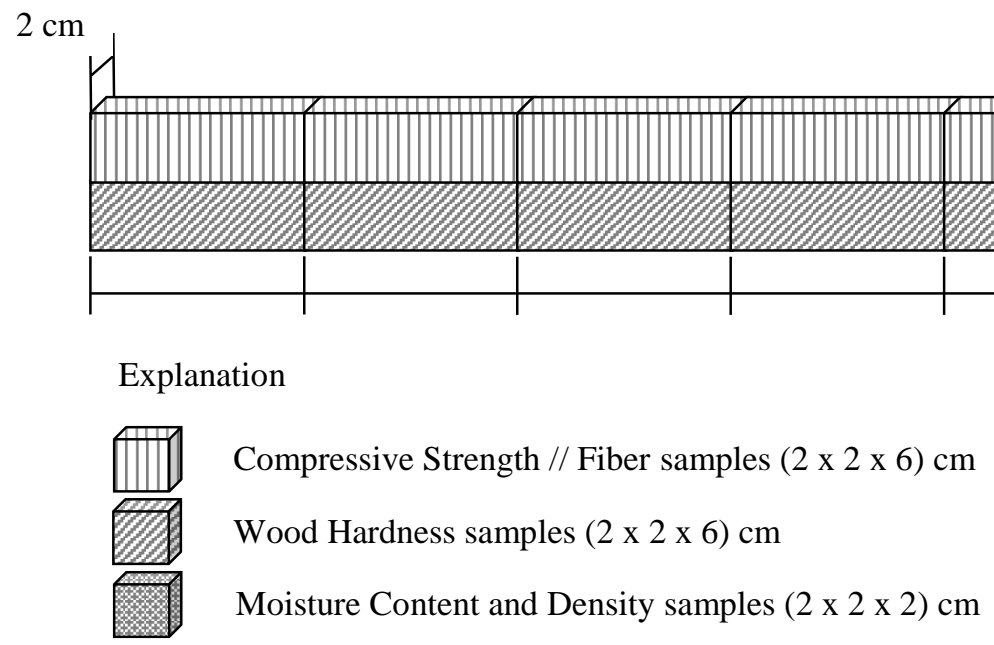

Figure 1 Position of each type of samples on the densified board
Before the densification process, the boards were dried until the moisture content reached $12-18 \%$ for about 6 weeks.

\subsection{Densification Process}

Pre-densification treatment was boiling the board samples for 45 minutes at $100{ }^{\circ} \mathrm{C}$ (wood was put after the water boiled) and after that the boards were directly wrapped with aluminum foil and inserted into the pressing machine for the process of pressing. The pressing was done after the temperature reaches $150{ }^{\circ} \mathrm{C}$. There are three heating times which are 0 minutes, 3 minutes, and 6 minutes and three initial thicknesses are $2.5 \mathrm{~cm}$, $3.0 \mathrm{~cm}$ and $3.5 \mathrm{~cm}$. The machine is turned off after the specified thickness and time have been reached and allowed to stand for 24 hours. After the densification process, the densified boards were dried again for about 6 weeks until the moisture content reached $12-18 \%$.

\subsection{Process of Making Test Samples}

From the wood samples of the densification process was made an example of physical and mechanical properties test according to predetermined size.The physical properties measured were moisture content, and the density, and the mechanical properties tested were compressive strength parallel to the fiber and hardness of wood.

The sample size for this physical properties test refers to JIS Z 2102 (1957) and JIS Z 2103 (1957) standards, while the sample size for testing mechanical properties refers to JIS Z 2113 (1963) standards. 


\subsection{Data Analysis}

This research used a completely randomized design, with a factorial experiment of 2 factors: initial thickness as factor $\mathrm{A}(2.5 \mathrm{~cm}, 3.0 \mathrm{~cm}$ and $3.5 \mathrm{~cm})$, and the heating time as factor $\mathrm{B}$ ( 0 minute, 3 minute and 6 minutes), whose each of samples under 5 repetitions.

\section{RESULT AND DISCUSSION}

\subsection{Physical Properties of Densified Sengon Wood (Paraserienthes falcataria)}

\subsubsection{Moisture Content}

Based on the results of the variance analysis showed that the initial thickness and the pressing time generally had a significant influence on the moisture content of sengon wood, and so did the interaction of both.

Based on the results of advanced dunnet test (Table 1 ), the moisture content of $16.42 \%$ on the densified board of the initial thickness of $3.0 \mathrm{~cm}$ with a moisture content of $17.61 \%$ control was significantly different. Differences of moisture content against the control for other thicknesses of $2.5 \mathrm{~cm}$ and $3.5 \mathrm{~cm}$ were not significantly different. This is in accordance with what was proposed by (2), that the heat will push water vapor out of the wood. Raised moisture content at the initial thickness of $3.5 \mathrm{~cm}$ was caused by the boiling process before densification so that boiling water comes in due to the widening of wood pores when it gets high temperature. When dried, some of the water trapped inside the pores cannot go all out without open treatment.

Table 1. Dunnet test results and MOE increase value

\begin{tabular}{cccccc}
\hline Treatment & $\begin{array}{c}\boldsymbol{\mu 1}(\text { Moisture } \\
\text { Content) }\end{array}$ & $\boldsymbol{\mu 2}(\mathbf{C o n t r o l )}$ & $|\boldsymbol{\mu 2}-\boldsymbol{\mu 1}|$ & DLSD & Increase $(\boldsymbol{\%})$ \\
\hline $2,5 \mathrm{~cm}$ & 17.03 & 17.61 & 0.57 & 0.98 & -3.26 \\
$3,0 \mathrm{~cm}$ & 16.42 & 17.61 & $1.19 @-6.77$ \\
$3,5 \mathrm{~cm}$ & 17.28 & 17.61 & 0.33 & 0.98 & -1.88 \\
\hline 0 minute & 17.37 & 17.61 & 0.46 & 0.98 & -1.33 \\
3 minutes & 16.98 & 17.61 & 0.34 & 0.98 & -3.55 \\
6 minutes & 16.37 & 17.61 & 0.22 & 0.98 & -7.03 \\
\hline
\end{tabular}

\subsubsection{Wood Density}

Based on the results of the variance analysis showed that the initial thickness and pressing time generally had a significant influence on the density of sengon wood, and so did the interaction between both.

Based on the result of dunnet test (table 20 which is an advanced test that serves to test the average of control with the average of treatment result showed that there has been an increase of density in all thickness against the average of control significantly.

According to [3], the density increases if the moisture content decreases to the saturation point of the fiber. The results showed that the density value of densified sengon wood increased compared to control sengon wood. Meanwhile, according to Tomme et al (1998), densification of wood can increase the density of wood because cell cavity and cell walls become denser and contain only a few hemicellulose in primary cell wall and middle lamella. Wood density correlates linearly with the strength of wood.

\subsection{Mechanical Properties of Sengon Densified Board}

\subsubsection{Compressive Parallel to Grain}

Based on the results of the variance analysis showed that the initial thickness and pressing time in general had a significant influence on the compressive strength parallel to sengon wood fiber, and so did the interaction between both.

The results of advanced dunnet test showed that the densification treatment given significantly influenced the initial thickness of $3.0 \mathrm{~cm}$ and $3.5 \mathrm{~cm}$, while the initial thickness of $2.5 \mathrm{~cm}$ did not give a significant influence. This indicated that with a $20 \%$ densification target it has not been able to increase the compressive strength parallel to fibers of the studied type of sengon. The result of this research (for $43 \%$ densification target) showed that the value was not much different from the result of research done by [4] to the type of agathis which showed that the compressive strength parallel to fiber with $50 \%$ densification increased almost 2 times or about $50 \%$. According to [4] the increase in value was smaller than the research conducted by [5], where densification in radial direction of $50 \%$ in Scub plywood can increase the 
Table 2. Dunnet test result and density increase value

\begin{tabular}{cccccc}
\hline Treatment & $\boldsymbol{\mu 1}$ (Density) & $\boldsymbol{\mu 2}$ (Control) & $|\boldsymbol{\mu} \mathbf{2} \boldsymbol{\mu} \mathbf{1}|$ & DLSD & Increase (\%) \\
\hline $2,5 \mathrm{~cm}$ & 0.3996 & 0.3483 & $0.05^{*}$ & 0.02 & 14.71 \\
$3,0 \mathrm{~cm}$ & 0.4718 & 0.3483 & $0.12^{*}$ & 0.02 & 35.44 \\
$3,5 \mathrm{~cm}$ & 0.5476 & 0.3483 & $0.20^{*}$ & 0.02 & 57.19 \\
\hline 0 minute & 0.4832 & 0.3483 & $0.13^{*}$ & 0.02 & 38.70 \\
3 minutes & 0.4541 & 0.3483 & $0.11 *$ & 0.02 & 30.37 \\
6 minutes & 0.4817 & 0.3483 & $0.13 *$ & 0.02 & 38.27 \\
\hline
\end{tabular}

Table 3. Dunnet test result and compressive strength parallel to fiber value

\begin{tabular}{cccccc}
\hline Treatment & $\begin{array}{c}\boldsymbol{\mu 1} \text { (Compressive strength } \\
\text { parallel to fiber) }\end{array}$ & $\boldsymbol{\mu 2}$ (Control) & $\boldsymbol{\mu \boldsymbol { \mu } - \boldsymbol { \mu 1 } |}$ & DLSD & Increase (\%) \\
\hline $2,5 \mathrm{~cm}$ & 302.85 & 287.75 & 15.11 & 41.57 & 5.25 \\
$3,0 \mathrm{~cm}$ & 333.87 & 287.75 & $46.12 *$ & 41.57 & 16.03 \\
$3,5 \mathrm{~cm}$ & 384.43 & 287.75 & $96.69^{*}$ & 41.57 & 33.60 \\
\hline 0 minute & 341.08 & 287.75 & $53.33 *$ & 41.57 & 18.53 \\
3 minutes & 320.93 & 287.75 & $33.18 *$ & 41.57 & 11.53 \\
6 minutes & 359.15 & 287.75 & $71.40 *$ & 41.57 & 24.82 \\
\hline
\end{tabular}

\subsubsection{Hardness Parallel to Pressing}

Based on the results of the variance analysis showed that the initial thickness and pressing time in general had a significant influence on the wood hardness parallel to the pressing, and so did the interaction between both.

Based on the results of advanced dunnet test it was seen that the treatment did not significantly influence the initial thickness of $2.5 \mathrm{~cm}$, indicating that the $20 \%$ of densification target has not been able to increase the hardness of sengon wood from the studied densification result. The result of this research (for $43 \%$ of densification target) the percentage value of wood hardness was the same as that done by [4] who examined the increase of hardness of agathist wood using densification, if in this research value increased almost 2 times, in Sulistyono research the value increased twofold more because the target of research in this research was also smaller than the research target of Sulistyono. [4] also said that the increase in hardness supports the results of previous research by [6].

In Table 4, it is seen that the hardness parallel to the pressing tends to increase from the pressing 0 minutes to 6 minutes; the increase is due to the increase of the heating time given so that the wood gets dry, and consequently, the wood becomes harder and stiffer. Such detail can be seen in the following histogram.

\subsubsection{Hardness Perpendicular to Pressing}

Based on the results of the variance analysis showed that the initial thickness and pressing time in general had a significant influence on the wood hardness perpendicular to the pressing, and so did the interaction between both.

Based on the results of advanced dunnet test, it is seen that the initial treatment of $3.5 \mathrm{~cm}$ had a significant influence on the increase of hardness perpendicular to pressing of the densified sengon wood and no significant influence on the initial thickness of $2.5 \mathrm{~cm}$ and $3.0 \mathrm{~cm}$. This indicated that the initial thickness of $2.5 \mathrm{~cm}$ and $3.0 \mathrm{~cm}$ is considered unable to increase the hardness perpendicular to pressing of densified sengon board. There are three cases of test results that are significantly different (marked with asterisk), insignificant (no asterisk) and insignificant (signed @), in the latter case if the MOE of densified board < MOE of control. This situation can be explained from the results of [7] research on the agathis and sengon densification showing that densification only occurs on the surface only because only the cells in that section are visibly flat, and the cell shape returns to normal in the center of the densified board.

It can be seen from Table 5 that the average hardness perpendicular to the pressing tends to increase from the pressing time of 0 minutes to 6 minutes, due to an increase in the amount of time the heating is given so that the wood becomes dry, resulting in the wood becoming harder and stiffer. All of the above can be summarized in Table 6. 
Table 4. Dunnet test result and hardness parallel to pressing value

\begin{tabular}{cccccc}
\hline Treatment & $\begin{array}{c}\boldsymbol{\mu 1} \text { (Hardness } \\
\text { parallel to pressing) }\end{array}$ & $\boldsymbol{\mu 2}$ (Control) & $|\boldsymbol{\mu} \mathbf{2} \boldsymbol{\mu} \mathbf{1}|$ & DLSD & Increase (\%) \\
\hline $2,5 \mathrm{~cm}$ & 200.13 & 171.00 & 29.13 & 35.41 & 17.04 \\
$3,0 \mathrm{~cm}$ & 211.13 & 171.00 & $40.13 *$ & 35.41 & 23.47 \\
$3,5 \mathrm{~cm}$ & 326.00 & 171.00 & $155.03^{*}$ & 35.41 & 90.64 \\
\hline 0 minute & 251.87 & 171.00 & $80.87^{*}$ & 35.41 & 47.29 \\
3 minutes & 227.33 & 171.00 & $56.33 *$ & 35.41 & 32.94 \\
6 minutes & 258.07 & 171.00 & $87.07 *$ & 35.41 & 50.92 \\
\hline
\end{tabular}

Table 5. Dunnet test result and hardness perpendicular to pressing value

\begin{tabular}{cccccc}
\hline Treatment & $\begin{array}{c}\boldsymbol{\mu 1}(\text { Hardness perpend to } \\
\text { press) }\end{array}$ & $\boldsymbol{\mu 2}$ (Control) & $|\boldsymbol{\mu} \mathbf{2}-\boldsymbol{\mu 1}|$ & DLSD & Increase(\%) \\
\hline $2,5 \mathrm{~cm}$ & 157.13 & 171.00 & $13.87 @$ & 41.25 & -8.11 \\
$3,0 \mathrm{~cm}$ & 203.07 & 171.00 & 32.07 & 41.25 & 18.75 \\
$3,5 \mathrm{~cm}$ & 261.67 & 171.00 & $90.67 *$ & 41.25 & 53.02 \\
\hline 0 minute & 206.87 & 171.00 & $35.87 *$ & 41.25 & 20.97 \\
3 minutes & 193.27 & 171.00 & $22.27 *$ & 41.25 & 13.02 \\
6 minutes & 221.73 & 171.00 & $50.73 *$ & 41.25 & 29.67 \\
\hline
\end{tabular}

Table 6. Dunnet test result based on the initial thickness \& heating times

\begin{tabular}{|c|c|c|c|c|c|c|c|c|}
\hline \multirow[b]{2}{*}{ No } & \multirow{2}{*}{$\begin{array}{c}\text { Physical and } \\
\text { Mechanical } \\
\text { Properties of Wood }\end{array}$} & \multicolumn{3}{|c|}{ Initial Thickness } & \multicolumn{3}{|c|}{ Heating Time } & \multirow[b]{2}{*}{ DLSD } \\
\hline & & $2,5 \mathrm{~cm}$ & $3,0 \mathrm{~cm}$ & $3,5 \mathrm{~cm}$ & 0 min. & 3 min. & $6 \mathrm{~min}$. & \\
\hline 1 & Moisture content & $0,57 @$ & $1.19 @$ & $0,33 @$ & $0.46 @$ & $0.34 @$ & $0.22 @$ & 0,98 \\
\hline 2 & Density & $0.05^{*}$ & $0.12 *$ & $0.20 *$ & $0.13 *$ & $0.11 *$ & $0.13 *$ & 0,02 \\
\hline \multirow[t]{2}{*}{3} & Compressive & & & & & & & \\
\hline & $\begin{array}{l}\text { Strength Parallel to } \\
\text { Fiber }\end{array}$ & 15,11 & $46.12^{*}$ & $96.69^{*}$ & $53.33 *$ & $33.18 *$ & $71.40 *$ & 41,57 \\
\hline 4 & $\begin{array}{l}\text { Hardness // to } \\
\text { Pressing }\end{array}$ & 29,13 & $40.13^{*}$ & $155,00^{*}$ & $80.87 *$ & $56.33 *$ & $87.07 *$ & 35,41 \\
\hline 5 & $\begin{array}{l}\text { Hardness } L \text { to } \\
\text { Pressing }\end{array}$ & 13,87@ & 32,07 & $90.67 *$ & $35.87 *$ & $22.27 *$ & $50.73 *$ & 41,25 \\
\hline
\end{tabular}

\section{CONCLUSION}

Compaction (densification) of sengon wood with the treatment of variation of thickness factor and variation factor of heating time based on the analysis of diversity indicates that not on all test of both factors have a real effect. Based on the results of dunnet test against the criteria of physical and mechanical properties tested then the best initial thickness to produce the compacted board type of sengon is $3.5 \mathrm{~cm}$, while the best effective seismic time is 6 minutes. The increasing moisture content at the initial thickness of $3.5 \mathrm{~cm}$ was caused by the boiling process done before the pressing takes place, so the wood boiled expands and the pores enlarges as the water enters and absorbs into the wood. The water that gets stuck in the pressing process takes longer to get it out.

\section{ACKNOWLEDGMENTS}

The researcher expressed his sincere appreciation to Mr. Rudianto Amirta as the Dean of the Faculty of Forestry at Mulawarman University as the organizer of the ISTFES activities. Also for my advisor in the Mulawarman University Forestry Science S3 program that has provided more information, advice and direction until the text is complete. Then for the State Agricultural Polytechnic of Samarinda, which has given me a lot of morals and finance.

\section{REFERENCES}

[1] I.Y. Wardhani, Kajian Sifat Dasar dan Pemadatan Bagian Dalam Kayu Kelapa (Cocos nucifera L), Disertasi Sekolah Pascasarjana Institut Pertanian Bogor, Bogor, 2005. 
[2] Y. Amin, W. Dwianto, Pengaruh suhu dan tekanan uap air terhadap fiksasi kayu kompresi dengan menggunakan close system compression, Jurnal Ilmu dan Teknologi Kayu Tropis, 4(2), 2006, pp. 19-24.

[3] J.G. Haygreen, J.L. Bowyer, Hasil Hutan dan Ilmu Kayu. Suatu Pengantar. UGM Press, Bulaksumur, Jogyakarta, 1996. (Terjemahan).

[4] Sulistyono, Studi Rekayasa Teknis, Sifat Fisis, Sifat Mekanis dan Keandalan Konstruksi Kayu Agatis (Agathis loranthifolia Salisb) Terpadatkan, Thesis Program Studi Ilmu Pengetahuan Kehutanan. Program Pascasarjana, Institut Pertanian Bogor, Bogor, 2001.

[5] T. Perkitny, W. Jablonski, Zur Beurteilung der mechanischen Eigenschaften vor Pressvollholz. Holz als Roh- und Werkstoff, 42, 1984, pp. 81-84.

[6] F.Ph. Tomme, F. Gigardet, B. Gfeller, P. Nafi, Densifiet wood: An innovative products with highly enchanced character, in: Proceeding $5^{\text {th }}$ wood conference on timber engineering vol. 2, Montreux, 1998.

[7] A. Hadiyane, Perubahan Sifat-Sifat Komponen Penyusun Kayu, Struktur Sel Kayu dan Sifat-Sifat Dasar Kayu Terdensifikasi Secara Parsial, Pascasarjana-IPB, Bogor, 2011. 